\title{
交流駆動両電極形静電モー夕の变調駆動
}

\author{
正員 新 野 俊 樹 (理 研) \\ 学生員 山本 晃 生 (東大院) \\ 正員樋口俊 郎 (東大院)
}

\section{Operation of Dual Excitation Multiphase Electrostatic Drive by Amplitude Modulated AC Voltage}

Toshiki Niino, Member (The Institute of Physical and Chemical Research (RIKEN)), Akio Yamamoto, Student Member, Toshiro Higuchi, Member (University of Tokyo)

Dual Excitation Multiphase Electrostatic Drive (DEMED) is a synchronous motor that is driven by electrostatic force. Because of its light weightiness, thinness and large power per weight ratio, it is expected as small-size motor and high-power motor in the future. Among three types of driving method that had been formerly developed for the motor, single frequency method is the most useful since it needs the least number of phases (three) of power supply. However, when the method drives the motor at such a very low speed as $10 \mu \mathrm{m} / \mathrm{s}$, the force generation decreases, and transformer cannot be used to obtain high voltage for the motor drive. In order to solve these problems, this paper proposes a novel supplemental operation method. In the new method that is named as "modulation drive," a 3-phase ac signal is amplitude-modulated with higher frequency carrier signal and applied to the electrodes. Being applied to the single frequency method, the modulation drive successfully drove the motor with typical audio power operational amplifiers that were boosted by transformers with ferrite core, and eliminated the force degradation at low driving speed. Additionally, the force generation of the modulation drive was analyzed, and the result agreed very well with experimental result.

キーワード: 静電モータ, 静電アクチェエータ, 静電力

\section{1.はじめに}

筆者らは軽量高出力モータの開発をめざし，様々なタイ プの静電モータの開発を行っている。それらの中で, 交流 駆動両電極形静電モータは, パワー密度 $230 \mathrm{~W} / \mathrm{kg}^{(1)}$ や, 推力

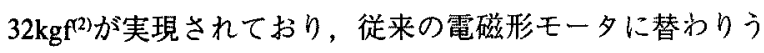
る軽量・高出力モータとして期待されている。これまでに 筆者らが考案してきた同期モータの一種であるこのモータ の様々な駆動方法(1)の中で, 1 周波数法は単一周波数の 3 相 交流電圧を電極に印加すればその周波数に比例した同期速 度が得られる最も簡易かつ有効な駆動方法である。しか し，印加する交流電压の周波数が低くなる低速の駆動にお いて，交流高電压を得るために変圧器を利用できない，推 力が低下するなどの問題がある。これらの問題を解決する 方法として, 新たに変調駆動法を考案したので, その基本 概念，推力特性に関して報告する。

\section{2. 交流駆動両電極形静電モータと従来の駆動法の 問題点}

交流駆動両電極形静電モータはフィルム状の移動子と固

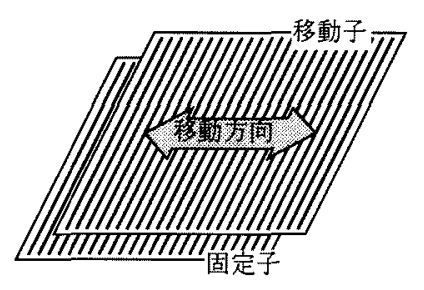

図 1 交流駆動両電極形静電モータの概形

Fig. 1 Overview of DEMED

定子から構成され(図 1)，移動子・固定子には 3 相の帯状 電極が等間隔で平行に配置されている。このモータの駆動 万法として筆者らは，2 周波数法，1 周波数法, AC-DC法 を提案してきた(1)。図 2 はこれら駆動法の中で最も基本的な 2 周波数法を説明する断面図である。2 周波数法では，移 動子・固定子の 3 相電極に周波数の異なる 3 相交流電圧を 印加する。移動子・固定子内には太線で示されるような正 弦波的な電位分布が発生し，2電位分布間に生ずる静電力 により，移動子は固定子表面上を電極に対して垂直な方向 に駆動される。このモータは同期モータであり，同期状態 で2 電位分布の間の空間的な位相差が一定に保たれ，2 電 位分布の進行速度差が移動子の同期速度となる。 


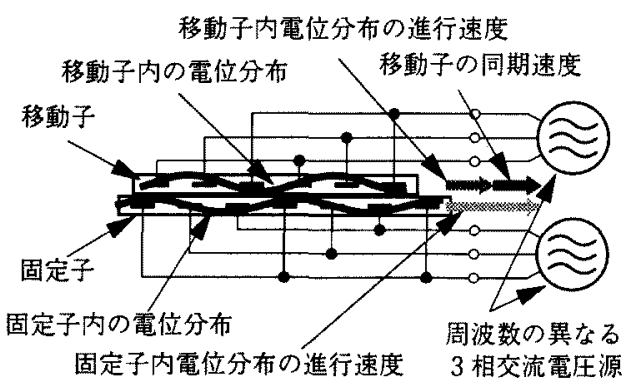

図 2 交流駆動雨電極形静電モー夕の駆動法 ( 2 周波数法)

Fig. 2 Schematic cross sectional view of ac DEMED (dual frequency method)

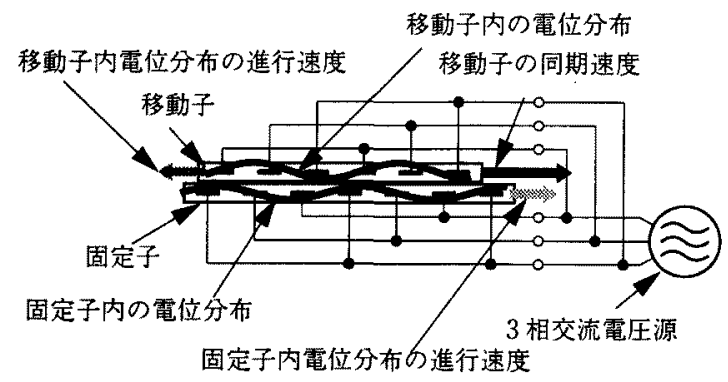

図 31 周波数法による駆動

Fig. 3 Single frequency method

現在，移動子·固定子はフレキシブルプリント基板の製

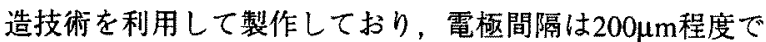
ある。この程度の電極間隔のモータによって電磁モー夕に 匹敵する出力を得るためには2000V程度の電圧印加が必要と なるが, この程度の電圧を発生できるアナログ增幅器は非 常に高価であり，このような増幅器を合計 6 個も必要とす る 2 周波数法は実用上問題がある。

駆動装置を䉮略化する方法のひとつとして，図3の1周 波数法がある。1 周波数法では， 3 相交流電圧を相順序を 反転して移動子・固定子の電極に印加することで，移動 子・固定子内に逆向きに同じ速さで進行する電位分市を励 起し， 2 電位分布の進行速度の差を得る。したがって，同 期速度は固定子内電位分布の進行速度の 2 倍となる。交流 高電圧の発生には変圧器が考えられるが, 印加電圧周波数 と駆動速度が比例する 1 周波数法では，低速駆動時に印加 する交流の周波数が低くなり变圧器鉄心が飽和する。ま た，低周波数の交流を印加した場合，モータの推力の低下 が生ずる。この現象の原因は明らかではないが，おそらく は, 電極間を絶縁している樹脂に長時間同一符号の電場が 印加されたために，電極周辺に空間電荷が蓄積され，電極 から発生する電場を弱めているためではないかと考えられ る。この現象は、モータをサーボモータとして利用して位 置決め制御を行うときなどの障害となる。

\section{3. 変調駆動法}

前節で述べた問題点を解決するために，新たに変調駆動 法を考案した。本節では, 変調駆動法の基本概念について

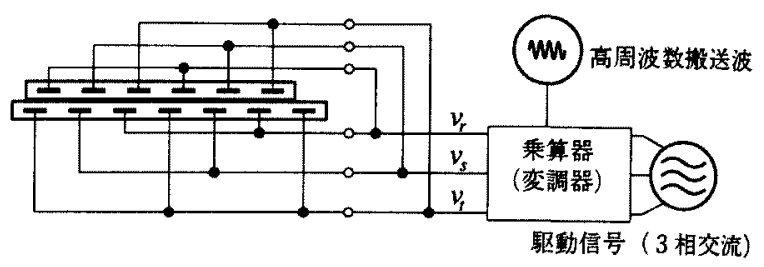

図 4 変調駆動の 1 周波数法への適用

Fig. 4 Application of modulation drive on single frequency method

説明する。図 4 に 1 周波数法に変調駆動法を導入する場合 の回路構成を示す。通常の 1 周波数法で 3 相交流電圧を直 接電極に印加するのに対し，変調駆動法では， 3 相交流電 圧を信号波として比較的高い周波数の搬送波に变調をかけ た電圧を電極に印加する。すなわち，通常の駆動法におけ る電極励起電圧 $v_{r}, v_{s}, v_{t}$ が

$$
\left(\begin{array}{l}
v_{r}=v_{0} \sin \omega_{s} t \\
v_{s}=v_{0} \sin \left(\omega_{s} t+\frac{2}{3} \pi\right) \\
v_{t}=v_{0} \sin \left(\omega_{s} t+\frac{4}{3} \pi\right)
\end{array}\right.
$$

であるのに対し，変調駆動法では

$$
\left(\begin{array}{l}
v_{r}=v_{0} \sin \omega_{c} t \sin \omega_{s} t \\
v_{s}=v_{0} \sin \omega_{c} t \sin \left(\omega_{s} t+\frac{2}{3} \pi\right) \\
v_{t}=v_{0} \sin \omega_{c} t \sin \left(\omega_{s} t+\frac{4}{3} \pi\right)
\end{array}\right.
$$

となる。ただし， $v_{0}, \omega_{s}, \omega_{c}$ はそれぞれ印加電圧の振幅，信号 波の角周波数，搬送波の角周波数である。このような電圧 印加を行えば，電極には常に搬送波周波数で交番する電圧 が印加され，低速駆動時および停止保持時に問題となる推 力の低下と変圧器の飽和の 2 点を回避できる。

次に, 変調駆動と通常駆動の駆動力を比較検討する。通 常駆動を行った場合の駆動力は，移動子・固定子内の電位 分布が完全な正弦波であり, 電極周辺の誘電率が均一であ ると仮定して単純化すれば，移動子・固定子内に発生する 電位分布の空間的な位相差によって決定される(3)。すなわ ち，(1)式の上うな電死印加を行った場合に移動子・固定子 内に発生する移動電位分布 $v_{s l}(t, x), v_{s t}(t, x)$ を，それぞれ

$$
\left(\begin{array}{l}
v_{s l}=v_{0} \sin \left(\omega_{s} t+\frac{2 \pi}{3 p}\left(x-x_{s l}\right)\right) \\
v_{s t}=v_{0} \sin \left(\omega_{s} t-\frac{2 \pi}{3 p} x\right)
\end{array}\right.
$$

と近似する。ここで，位置座標は図 5 中右向きを正とし， また， $x_{s l}, p$ はそれぞれ，移動子の固定子に対する位置，電 極の配置間隔である。このとき，2電位分布間の空間的位 相差 $\delta は$ 


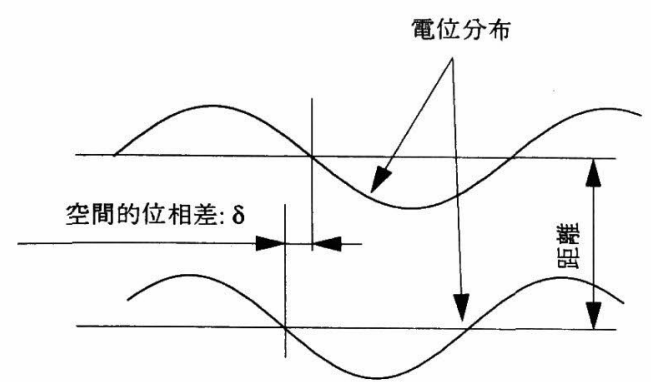

図 5 移動子 · 固定子中の電位分布の位相差

Fig. 5 Phase difference between potential distributions in the slider and the stator

$$
\delta=-2 \omega_{s} t+\frac{2 \pi}{3 p} x_{s l}+\pi .
$$

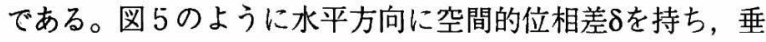
直方向にある距離を有する 2 電位分布間に発生する水平方 向の面積あたりの力 $f_{x}$ は,

$$
f_{x}=\frac{\varepsilon v_{0}^{2}}{\lambda^{2}} \widehat{\kappa}_{t} \sin \delta
$$

と求めることができる(3)。ここで， $\varepsilon, \lambda は$ ，それぞれ電位分 布が置かれている空間の誘電率, 電位分布の波長であり,

$\widehat{\kappa}_{t}$ は波長と 2 電位分布間の距離との比で決定される無次元 の定数である。移動子 · 固定子の電極が向き合う面積(以降 有効電極面積) がSであるモー夕の発生する水平方向の力 $F_{x}$ は,

$$
\begin{aligned}
& F_{x}=\kappa_{t} v_{0}^{2} \sin \left(2 \omega_{s} t-\frac{2 \pi}{3 p} x_{s l}\right) . . \\
& \kappa_{t}=\widehat{\kappa}_{t} \frac{\varepsilon}{\lambda^{2}} S
\end{aligned}
$$

となる。

変調駆動を行った場合の推力 $F_{\bmod x}$ は，(6)式において $v_{0}$ を $v_{0} \sin \omega_{c} t$ に置き換えることによって求めることができ，

$$
F_{\bmod x}=\kappa_{t} v_{0}^{2} \sin ^{2} \omega_{c} t \sin \left(2 \omega_{s} t-\frac{2 \pi}{3 p} x_{s l}\right)
$$

となる。駆動周波数に対して搬送波周波数が十分高いとす れば, 搬送波の周期程度の期間の推力変化は平均化して取 り扱うことができ， $F_{\bmod x}$ を $\sin ^{2} \omega_{c} t$ にいてのみ 1 周期分の 積分を行えば，実際に測定されるモー夕の発生力 $F_{\bmod x}$ は,

$$
\begin{aligned}
& F_{\bmod x}=\frac{\omega_{c}}{2 \pi} \int_{0}^{\frac{2 \pi}{\omega_{c}}} \kappa_{t} v_{0}^{2} \sin ^{2} \omega_{c} \tau \sin \left(2 \omega_{s} t-\frac{2 \pi}{3 p} x_{s l}\right) d \tau \\
& =\frac{1}{2} \kappa_{t} v_{0}^{2} \sin \left(2 \omega_{s} t-\frac{2 \pi}{3 p} x_{s l}\right)
\end{aligned}
$$

となる。(8)式を(6)式と比較すると，推力の值が常に1/2に なっている以外の違いはない。すなわち, 変調駆動の推力

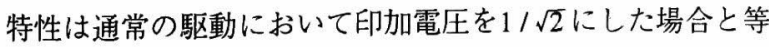
価である。

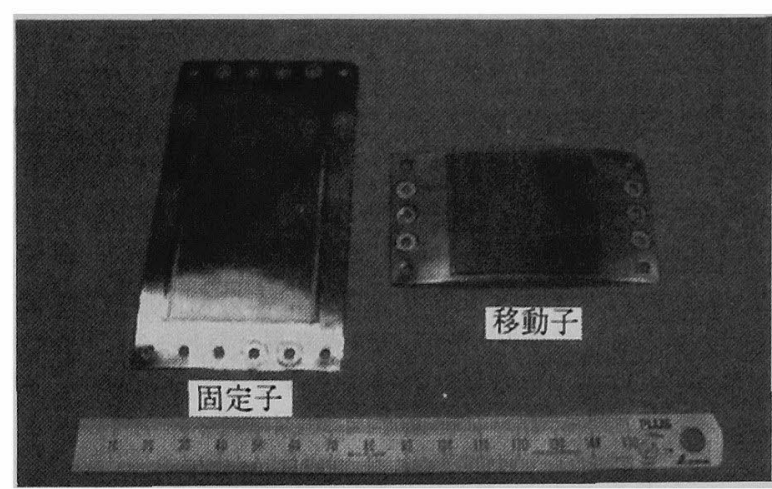

図 6 実験に使用した移動子・固定子

Fig. 6 Stator and slider used in the experiments

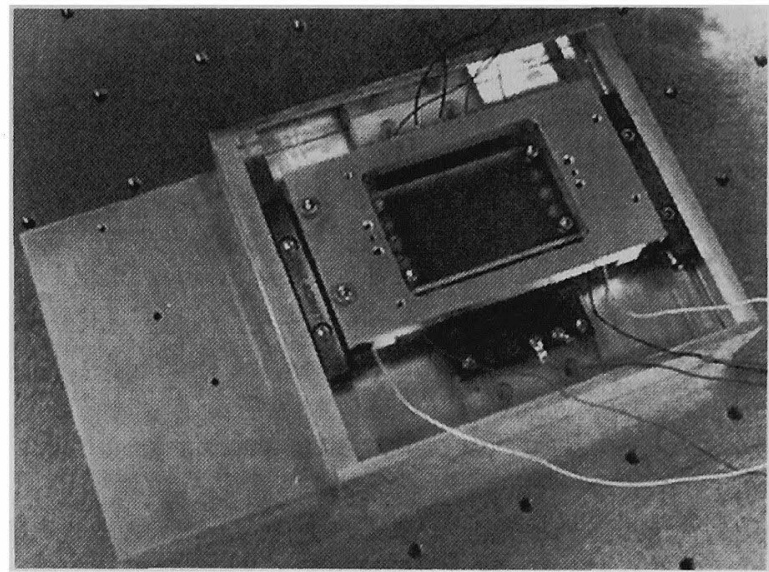

図 7 積層モー夕

Fig. 7 Stacked motor

\section{4. 実 験}

\section{$<4$ 1>実験に用いたモータ}

図 6 に示すような移動子・固定子をフレキシブルプリン 卜基板製造技術を利用して製作した。移動子・固定子内の 電極の配置間隔，長さはそれぞれ $200 \mu \mathrm{m} ， 40 \mathrm{~nm}$ であり，有 効電極面積は $16 \mathrm{~cm}^{2}$ である。モー夕推力のリプルを抑制する ため電極にはスキューが施してある(4)。このような移動子． 固定子各 8 枚を交互に積層して積層モー夕(2)を構成し(図 7 ), 駆動実験を行った。

\section{$<4 \cdot 2>$ 変圧器を用いた駆動}

変調駆動法の一つの利点として, 低速運転においても変 圧器で電压を昇圧することにより，低電圧出カアンプに よってモー夕を駆動することが可能である点がある。この 利点を確認するために，図 8 のような駆動回路を構成し， モータの駆動を試みた。駆動電圧波形の生成は，変調まで 含めてDSPシステムで行った。増幅回路の終段には高出力 演算増幅器 (National Semiconductor製 LM12CLK)を用いた。 LM12CLKは一般的にサーボアンプやオーディオアンプに用 いられ，推奨される電源電圧 $\pm 30 \mathrm{~V}$ 時に $\pm 25 \mathrm{~V}$ 電圧出力が可 能であり，80Wの出力パワーを有する。増幅回路の出力は フェライトをコア (TDK製 $\mathrm{PQ} 50 / 50$ ，代表寸法 $50 \mathrm{~mm}$ ，磁路 断面積 $328 \mathrm{~mm}^{2}$ ) とする変圧器 (図 9 ) に入力される。変圧器 


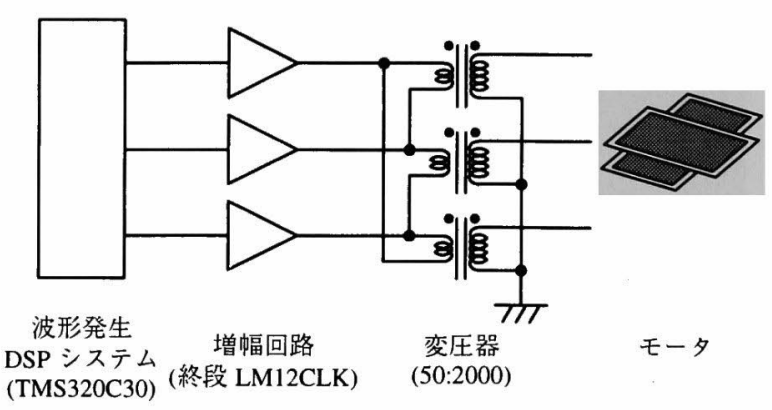

図 8 変圧器を用いた駆動回路

Fig. 8 Driving circuit employing transformers

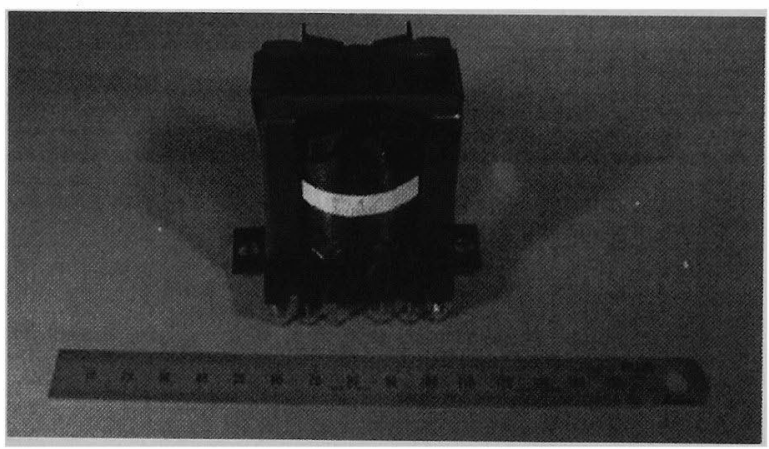

図 9 駆動に用いた変圧器

Fig. 9 Transformer employed for the experiment

の巻数は 1 次側 50 巻, 2 次側 2000 巻とし, 1 次側, 2 次側 をそれぞれデルタ，スター結線として 3 相変圧回路を構成 し, 変圧器 2 次側にはモータが接続される。

変圧器で高電圧を発生するときにコアの飽和を防ぐため には，1. 周波数を高くする，2.コイルの巻数を増や す， 3 ．磁路にギャップを入れるの 3 通りの方策が取られ るが, 搬送波周波数を高くすると, 容量性の負荷である静 電モータのインピーダンスが低くなり，増幅回路への無効 電流分の負荷が増大する。また，小さなコアではコイルの 巻数にも制限がある。そこで今回は, 磁路中に0.6mmの工 アギャップをいれ，搬送波周波数を低下させた。

図１0，１１に前述の積層モータを駆動したときのアン プの出力電圧, 電流, モータへの供給電圧, 電流を示す。 なお，搬送波周波数は $1 \mathrm{kHz} ， モ ー 夕 は$ 無負荷で運転し，電 流は電流プローブ(Tektronix A6302)で測定した。

\section{$<4 \cdot 3>$ 駆動力の測定}

図 12 に通常の 1 周波数法と, 変調駆動の 1 周波数法に よって駆動したときの，駆動力と印加電圧の関係を示す。 駆動力は，おもりの重力を木綿糸を介して移動子にあた え，引き上げ可能な最大のおもりの質量とした。印加電圧 は 3 相交流の実効值電圧である。駆動周波数は $1 \mathrm{~Hz}$ (同期速 度 $1.2 \mathrm{~mm} / \mathrm{s}$ に対応), 变調駆動の搬送波周波数は $1 \mathrm{kHz}$ であ る。通常駆動の電圧発生には高電圧アナログアンプを用い た。(8)式の結果を確認するために, 変調駆動の印加電圧を $1 / \sqrt{2}$ にしたものを等価印加電圧として書き直したものを図 13 に示す。図中，2種類の駆動方法による駆動力と等価
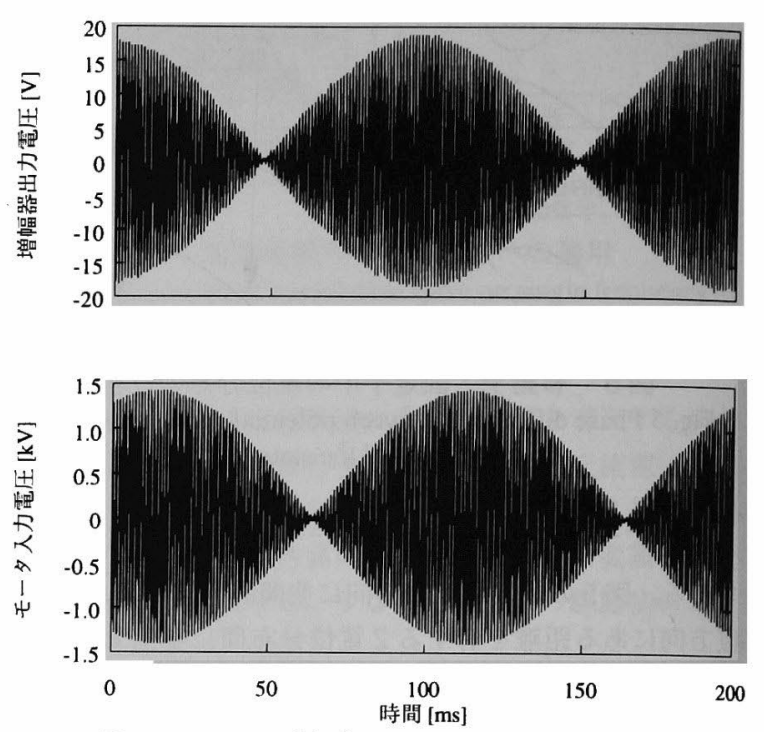

図 10 アンプ出力電圧とモータ入力電圧

Fig. 10 Voltages of driver output and motor input
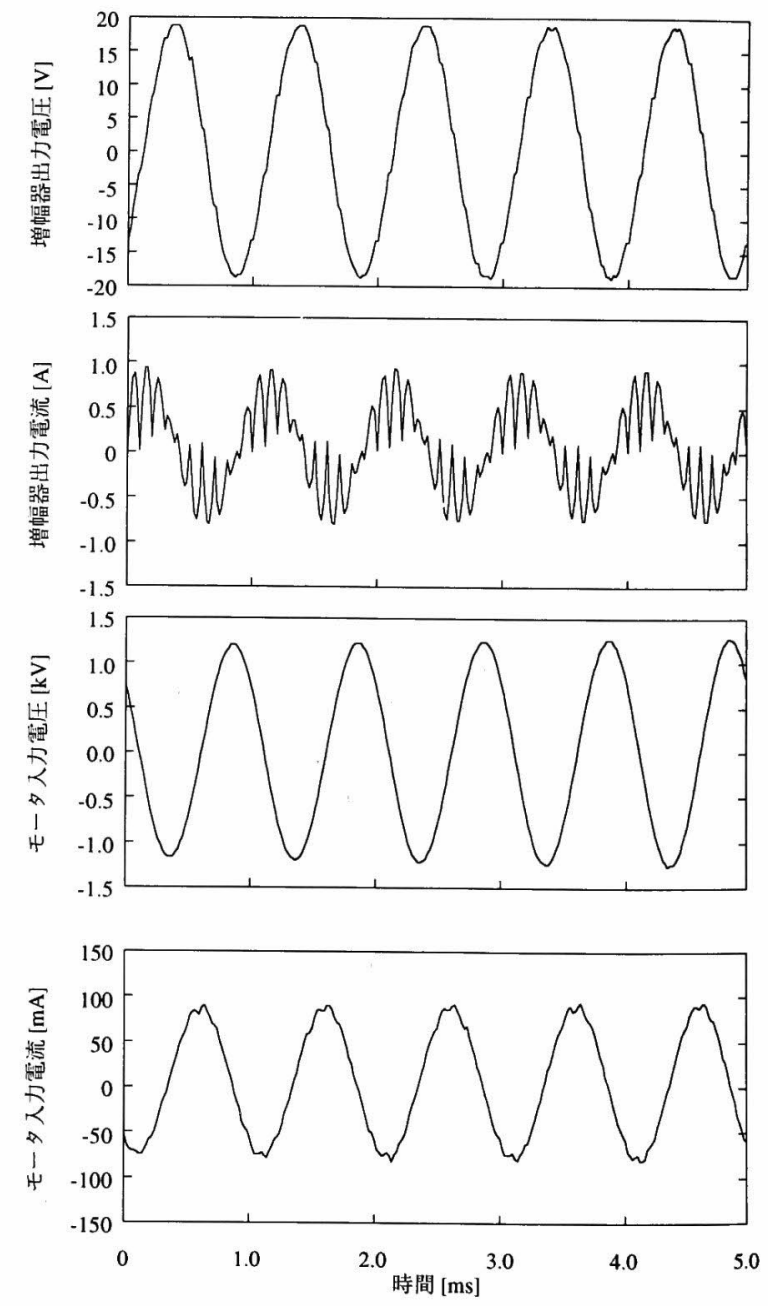

図 11 各部の電圧及び電流

Fig. 11 Voltages and currents of driver output and motor input 


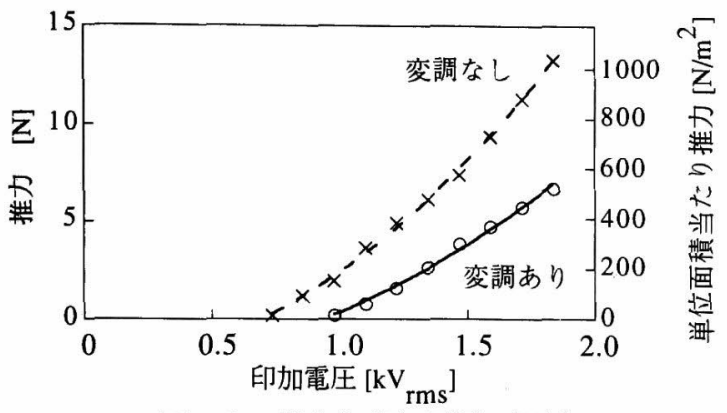

図 12 推力と印加電圧の関係

Fig. 12 Relationship between thrust force and applied voltage

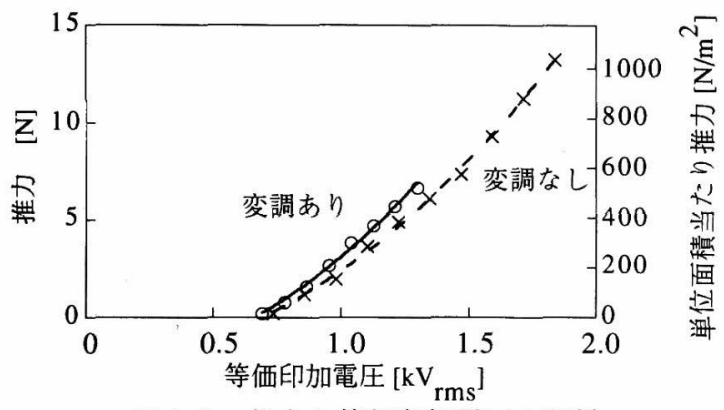

図 13 推力と等価印加電圧の関係

Fig. 13 Relationship between thrust force and equivalent applied voltage

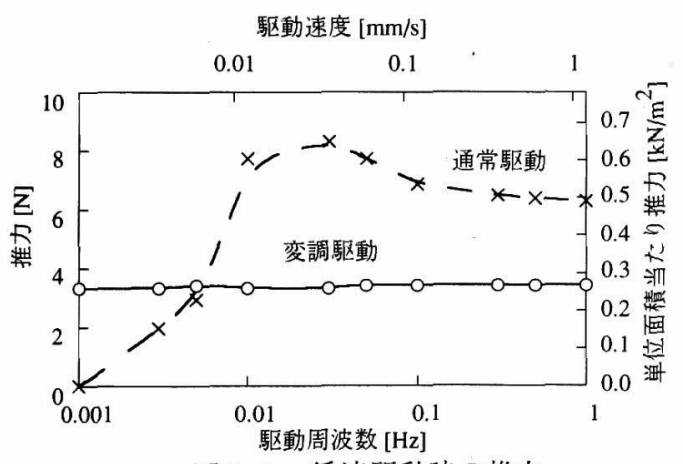

図 14 低速駆動時の推力

Fig. 14 Thrust force when motor is driven at very low speed

\section{印加電圧の関係はほぼ一致しており，(8)式の妥当性が確認} できた。

\section{$<4 \cdot 4>$ 低速駆動時の推力の比較}

低速駆動時の変調駆動法の効果を確認するために, 通常 駆動・変調駆動の 2 種類の駆動法で, 低速駆動時の推力の 測定を行った(図 144$)$ 。なお，変調駆動の搬送波周波数は 前節の実験と同一であり，印加電圧は $1.5 \mathrm{kV}_{\mathrm{rms}}$ である。通常 駆動法では, 駆動周波数 $0.01 \mathrm{~Hz}$ 以下で推力が急激に低下し ているのに対し，変調駆動法では，駆動周波数に関わらず 常に一定の推力が得られることを確認した。また，1時間 の停止保持後にも直ちに駆動可能であることを確認した。

\section{5. をとめ}

交流駆動両電極形静電モータの従来の駆動方法に付加す る駆動方法として, 変調駆動方法を考案した。この駆動法 は, 従来の駆動に用いられていた電圧を，高周波数の交流 を搬送波として, 振幅変調(搬送波抑圧両側帯波変調) して 電極に印加する。変調駆動法を導入したときの推力は，印 加電圧を $1 / \sqrt{2} に し て$ 通常駆動法を行った場合と等価である ことを解析的にもとめ，実験結果もそれとよく一致した。

この駆動方法により，低速運転時の推力の低下の問題が 解決できることが実験的に証明された。また，従来モー夕 の低速駆動には不可欠であった高電圧出力増幅器にかえて 一般的なオーディオアンプ程度の増幅器とフェライトコア 変圧器の組み合わせでも駆動可能であることを確認した。

(平成 9 年 11 月 5 日受付, 同 10 年 7 月 2 日再受付)

\section{文献}

(1) T. Niino, S. Egawa and T. Higuchi:"High-power and High-efficiency Electrostatic Actuator," Proc. 1993 IEEE Workshop on Micro Electro Mechanical Systems, pp. 236-241

(2) T. Niino, S. Egawa, H. Kimura and T. Higuchi: "Electrostatic Artificial Muscle: Compact, High-Power Linear Actuators with Multiple-Layer Structures," Proc. 1994 IEEE Workshop on Micro Electro Mechanical Systems, pp. 130-135

(3) T. Niino, S. Egawa and T. Higuchi: "Ac Drive Electrostatic Linear Motor," Proc. IEEJ 1995 International Power Electronics Conference, pp. 1696-1701

(4) 山本晃生, 新野俊樹, 坂 高寿, 婳口俊郎：「スキュー電極を用い た高出力静電モー夕」電学論 D, 117, pp. 1139-1145(平9-9)

新野 佁樹 (正員) 1966 年9月18日生。95年 3 月東京大学大学院博

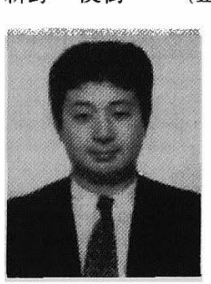
士課程修了。97年 3 月理化学研究所に入所。静電 モー夕, 光造形装置の開発に携わる。IEEE, 精密 工学会, ロボット学会。博士(工学)。

山本 晃生 (学生員) 1972年3月17日生。96年3月東京大学大学院工

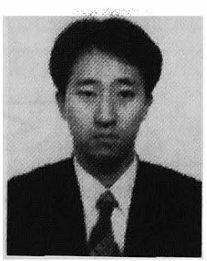
学系研究科修士課程 (精密機械工学専攻) 修了。同 年4月同大学院博士課程進学。現在に至る。

桶口＼cjkstart俊郎（正員)1950年2月26日生。1977年東京大学大学院博士

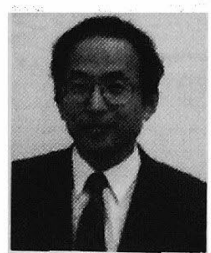
課程修了。同年, 同大学生産技術研究所講師, 1978年同助教授, 1991 年11月同大学大学院工学系 研究科教授，92年 4 月上り，(財)神奈川科学技術 アカデミー桶口「極限メカトロニクス」プロジェク トリーダを兼任，現在に至る。工学博士。 